\title{
Basil, tea tree and clove essential oils as analgesics and anaesthetics in Amphiprion clarkii (Bennett, 1830)
}

\author{
A. M. Correia ${ }^{a}$, A. S. Pedrazzani ${ }^{a}$, R. C. Mendonça ${ }^{a}$, A. Massucatto ${ }^{a}$, R. A. Ozório ${ }^{a}$ \\ and M. Y. Tsuzuki ${ }^{a}$ \\ ${ }^{a}$ Laboratório de Peixes e Ornamentais Marinhos - LAPOM, Departamento de Aquicultura, Universidade Federal de Santa \\ Catarina - UFSC, Rodovia Admar Gonzaga, 1346, Itacorubi, CEP 88034-001, Florianópolis, SC, Brazil \\ *e-mail: neacorreia@yahoo.fr
}

Received: July 15, 2016 - Accepted: January 12, 2017 - Distributed: October 31, 2018

(With 1 figure)

\begin{abstract}
In this study were evaluated the anaesthesia and analgesic effects of clove Eugenia caryophyllata, tea tree Melaleuca alternifolia and basil Ocimum basilicum essential oils (EO) during handling of yellowtail clownfish Amphiprion clarkii. Juveniles ( $3.70 \pm 0.75 \mathrm{~cm}$ and $1.03 \pm 0.50 \mathrm{~g}$; mean \pm standard deviation) were submitted to concentrations of 40, 50, 60, 70 and $80 \mu 1 \mathrm{~L}^{-1}$ of clove, 150, 200, 250, 300 and $350 \mu 1 \mathrm{~L}^{-1}$ of basil and 200, 300, 400, 500 and $600 \mu 1 \mathrm{~L}^{-1}$ of tea tree oils ( $\mathrm{n}=10$ /concentration), previously defined in pilot tests. Individually and only once, fish from each treatment were placed in a glass recipient containing $1 \mathrm{~L}$ of seawater at a temperature of $25^{\circ} \mathrm{C}$, salinity of $35 \mathrm{~g} \mathrm{~L}^{-1}$ and the specific concentration of diluted EO (stock solution). Control (only seawater) and blank (seawater and ethanol at the highest concentration used to dilute the oils) treatments were also conducted. After reaching the stage of surgical anaesthesia, fish were submitted to biometry and a sensibility test. After that, they were transferred to clean seawater for anaesthesia recovery. The times of induction needed to reach each anaesthesia stage and anaesthesia recovery were recorded. Animals were observed for 72 hours after the procedures. All the EO provoked anaesthesia and analgesic effects in A. clarkii, but basil oil is not recommended because it caused involuntary muscle contractions and mortality in $100 \%$ and $12 \%$ of fish, respectively. The lower concentrations that promote suitable induction and recovery times are $50 \mu \mathrm{L} \mathrm{L}^{-1}$ of clove oil and $500 \mu \mathrm{L}^{-1}$ of tea tree oil. However, due to its complementary high analgesic efficiency, clove oil is recommended as the ideal anaesthetic for $A$. clarkii.
\end{abstract}

Keywords: Eugenia caryophyllata, marine ornamental aquaculture, Melaleuca alternifolia, Ocimum basilicum, yellowtail clownfish.

\section{Óleos essenciais de manjericão, melaleuca e cravo como anestésicos e analgésicos em Amphiprion clarkii (Bennett, 1830)}

\begin{abstract}
Resumo
Neste estudo foram avaliados os efeitos anestésicos e analgésicos dos óleos essenciais (OE) de cravo Eugenia caryophyllata, melaleuca Melaleuca alternifolia e manjericão Ocimum basilicum durante manejo de peixes-palhaços Amphiprion clarkii. Juvenis ( $3.70 \pm 0.75 \mathrm{~cm}$ e $1.03 \pm 0.50 \mathrm{~g}$; média \pm desvio padrão) foram submetidos às concentrações de $40,50,60,70 \mathrm{e} 80 \mu 1 \mathrm{~L}^{-1}$ de cravo, 150, 200, 250, 300 e $350 \mu 1 \mathrm{~L}^{-1}$ de manjericão e 200, 300, 400, 500 e $600 \mu 1 \mathrm{~L}^{-1}$ de melaleuca (n=10/concentração), previamente definidas em testes pilotos. Individualmente e somente uma vez, os peixes de cada tratamento foram colocados em recipiente de vidro contendo $1 \mathrm{~L}$ de água salgada, em temperatura de $25^{\circ} \mathrm{C}$, salinidade de $35 \mathrm{~g} \mathrm{~L}^{-1} \mathrm{e}$ a concentração específica de $\mathrm{OE}$ diluída (solução estoque). Tratamentos controle (apenas água marinha) e branco (água marinha e a maior concentração de etanol utilizada para diluição dos óleos) também foram conduzidos. Após atingirem o estágio de anestesia cirúrgica, os peixes foram submetidos à biometria e teste de sensibilidade. Em seguida, foram transferidos para água marinha limpa. Os tempos necessários para atingir cada estágio anestésico e recuperação foram registrados. Os animais foram observados por 72 horas após os procedimentos. Todos os OE provocaram anestesia e analgesia em A. clarkii, porém o óleo de manjericão não é recomendado, pois causou contrações musculares involuntárias e mortalidade em $100 \%$ e $12 \%$ dos animais, respectivamente. As menores concentrações que promovem indução anestésica e recuperação em tempos adequados são $50 \mu 1 \mathrm{~L}^{-1}$ de óleo de cravo e $500 \mu 1 \mathrm{~L}^{-1}$ de óleo de melaleuca. Entretanto, devido à sua alta eficiência analgésica complementar, o óleo de cravo é recomendado como o anestésico ideal para A. clarkii.
\end{abstract}

Palavras-chave: Eugenia caryophyllata, aquicultura ornamental marinha, Melaleuca alternifolia, Ocimum basilicum, peixe-palhaço de cauda amarela. 


\section{Introduction}

The Pomacentridae family (Teleostei: Perciformes), particularly the species of the Amphiprion genus, represents the most important group of marine fish in aquariums (Johnston et al., 2003). The clownfish Amphiprion clarkii lives in association with anemone, and is the most widely distributed reef fish, found naturally through the Indo-Pacific Ocean (Pinsky et al., 2010), and its production has been successfully achieved in captivity (Ye et al., 2011).

It is known that during cultivation and commercialization, fish are submitted to handling procedures that are capable of causing physiological alterations, related to stress responses, which directly influence the animal's welfare (Sneddon, 2003; Bergqvist and Gunnarsson, 2013). Moreover, there is growing recognition that fish are capable of nociception, i.e., are able to perceive noxious stimuli, can consciously experience fear, pain and suffering (Sneddon 2003, 2011; Ross and Ross, 2008). Sedative and analgesic substances have been used to facilitate handling and to prevent physical injuries and pain during the procedures, minimizing the harmful effects of stress and mortalities (Inoue et al., 2003; Ross and Ross, 2008). However, research pharmacological that provides analgesic drugs and dosages for fish is scarce in veterinary literature and anaesthetic agents in these animals may not always provide analgesic effects (Weber III, 2011). Thus it is necessary to test the analgesic efficacy of new substances to provide relief from pain that may be caused by painful stimuli in the animals during handling.

Various synthetic products, such as tricaine methanesulphonate (MS-222), quinaldine sulphate, benzocaine and 2-phenoxyethanol are widely used to anesthetize fish. Nevertheless, negative effects, such as loss of mucus, gill irritation and cornea damage can be observed (Inoue et al., 2003), as well as the carcinogenic potential of some products (Pirhonen and Schreck, 2003). In addition, they can be of limited use or prohibited (Iversen et al., 2003). Thus, for these reasons, there is a growing demand for low-cost anaesthetic products that are easy to obtain and offer security to the animals, to the handlers and to the environment. Some essential oils (EO) derived from plants have been shown to be a viable alternative to reduce stress during fish capture and handling (Silva et al., 2013). Different oils have been used to anaesthetize fish, such as Eugenia caryophyllata (Weber et al., 2009; Pawar et al., 2011), Cinnamomum camphora, Mentha arvensis (Pedrazzani and Ostrensky, 2014), Melaleuca alternifolia (Hajek, 2011), Ocimum gratissimum (Benovit et al., 2012), Hesperozygis ringens and Ocotea acutifolia (Silva et al., 2013).

Clove oil, extracted from Eugenia caryophyllata Thunberg (i.e. Syzigium aromaticum, Myrtaceae), is a recognized anaesthetic in vertebrates and invertebrates (Ross and Ross, 2008) and, according to Boijink et al. (2017), is commonly used in Brazilian aquaculture. Its main component, eugenol (4-allyl-2-methoxyphenol), is considered as a safe substance, because of its absence of side effects (Soto and Burhanuddin, 1995; Ross and Ross, 2008). Nevertheless, there is no information about the ideal concentration for A. clarkii anaesthesia or the analgesic effect in this species.

Melaleuca alternifolia Cheel (Myrtaceae) is known for the antifungal, bactericide and anti-inflammatory actions of its main component, terpinen-4-ol (Carson et al., 2006). A commercial product based on the $\mathrm{EO}$ of tea tree is commonly used as a cicatrizant medicine in ornamental fish. Nevertheless, studies about its anaesthetic efficacy in fish are scarce (Hajek, 2011).

Another plant species that has potential for use as an anaesthetic in fish is basil Ocimum basilicum L. (Lamiaceae). Basil has an analgesic effect in humans, providing a local anaesthetic effect, and is a central nervous system (CNS) depressant (Bilal et al., 2012; Pandey et al., 2014). Nevertheless, scientific studies about its use as an anaesthetic or analgesic in fish is unknown. Therefore, the aim of this study was to evaluate the efficacy of different concentrations of clove, tea tree and basil EO for anaesthesia and analgesia in yellowtail clownfish A. clarkii.

\section{Material and Methods}

The study was conducted at the Laboratório de Peixes e Ornamentais Marinhos (LAPOM) of the Universidade Federal de Santa Catarina (UFSC), Florianópolis, Santa Catarina, Brazil in December 2014.

\subsection{Animal maintenance}

The study used $170 \mathrm{~A}$. clarkii $(1.03 \pm 0.50 \mathrm{~g}$ in weight and $3.70 \pm 0.75 \mathrm{~cm}$ in total length, mean \pm standard deviation) cultivated at a density of $0.5 \mathrm{fish} \mathrm{L}^{-1}$ in an open system at $25.5 \pm 1.5^{\circ} \mathrm{C}$, constant aeration, and salinity of $35 \pm 1 \mathrm{~g} \mathrm{~L}^{-1}$. Fish were fed until apparent satiety twice a day with a commercial marine ornamental fish diet (Inve, Belgium), and deprived of food for 24 hours before the experiments.

\subsection{Essential oils}

The essential oils were acquired and the composition of the products were informed by the producer company through technical reports (clove Eugenia caryophyllata: eugenol $=86 \%$; tea tree Melaleuca alternifolia: terpinen-4-ol $=42 \%$ and gamma-Terpinene $=22 \%$; basil Ocimum basilicum: methyl chavicol $=84 \%$ ). Stock solutions were prepared by diluting each essential oil in ethyl alcohol $92.8 \%$ at a proportion of $1: 10$, stored in properly identified amber glass flasks, and protected from humidity, light and heat sources.

\subsection{Experimental procedure}

Initially, pilot tests were conducted following the method proposed by Pedrazzani and Ostrensky (2014) to determine the oil concentrations to be tested in this study. Then, the fish were submitted to five different concentrations of each EO $(n=10 /$ concentration $)$ previously defined (clove: 40, 50, 60, 70 and $80 \mu \mathrm{L} \mathrm{L}^{-1}$; basil: 150, 200, 250, 300 and $350 \mu \mathrm{L} \mathrm{L}^{-1}$; and tea tree: 200, 300, 400, 500 and $600 \mu \mathrm{L} \mathrm{L}^{-1}$ ) A blank group, in which only the highest ethanol concentration used to dilute 
the essential oils ( $\left.540 \mu \mathrm{L} \mathrm{L}^{-1}\right)$ was added to seawater and a control group, without substances added to seawater, were also evaluated.

Individually and only once, fish from each treatment were placed in a glass recipient containing $1 \mathrm{~L}$ of seawater at a temperature of $25{ }^{\circ} \mathrm{C}$, salinity of $35 \mathrm{~g} \mathrm{~L}^{-1}$ and the specific concentration of diluted EO (stock solution). Tests were always conducted from the lowest to the highest concentration of anaesthetic. The solutions were discarded and the recipients were washed with neutral detergent and water, rinsed with alcohol and dried to initiate the procedures on the subsequent animal. During the entire process, fish were monitored visually and the times needed to reach anaesthesia stages were timed and recorded (Table 1).

Immediately after reach anaesthesia stage IV, the fish were removed from the glass recipient, lightly dried with paper towels, weighed and measured (total length, standard length and height), simulating routine biometry. To verify the analgesic effect, a sensibility test was conducted by lightly pressing a needle to the lip of each fish, where nociceptor fibres are usually found (Sneddon, 2003). Any reaction indicating discomfort (such as opening mouth or jumping) was recorded as absence of analgesic effect.

To evaluate recovery, fish were immediately placed in another glass recipient containing $1 \mathrm{~L}$ of clean seawater with constant aeration. Animals were considered to be recovered when they responded to visual stimuli (movement of an object close to their head) and reached a horizontal swimming position, indicating an apparent return to equilibrium. The recovery time was measured and recorded.

After recovery, fish were transferred to 17 net cages (one for each treatment) immersed in an open seawater system with similar characteristics as found before the experiment. They were fed 12 hours after the experiment. Mortality and possible atypical behaviour, such as lack of interest in food (ingestion) and absence of or difficulty in swimming were recorded at 24, 48 and 72 hours after the experiment.

\subsection{Statistical analysis}

The results obtained from each EO were analysed separately and the performances of their concentrations were compared. Normality of the data was evaluated with the Shapiro-Wilk test. Since the data were non-parametric, the Kruskall-Wallis test was used to compare induction and recovery periods. The correlations between induction and recovery times were evaluated by linear regression. The level of significance of $95 \%(p<0.05)$ was adopted for all analyses.

\section{Results and Discussion}

None of the fish in the control and blank groups presented any anaesthesia effect, as also observed by Sepulchro et al. (2016), or any analgesic effect, demonstrating a response (nociception) to painful stimuli through jumps or open mouth. This highlights the need to seek methods to relieve or prevent pain during handling in order to preserve animal welfare, avoiding stress and harm to fish. In contrast, all the concentrations of EO promoted analgesia and anaesthesia in the animals. There was a significant difference between the concentrations of EO in relation to the time of anaesthetic induction (stage IV), with shorter times observed at higher concentrations (Figure 1). This relation between the increase of EO concentration and the decrease of anaesthesia induction period was also observed in the fat snook Centropomus parallelus anaesthetized with eugenol, menthol and benzocaine (Souza et al., 2012), in sole Solea senegalensis anaesthetized with 2-phenoxyethanol, metomidate, clove oil and MS-222 (Weber et al., 2009) and in grouper Epinephelus bruneus using clove oil (Park et al., 2008). Such characteristic demonstrated that the increase of concentration elevates the potential for absorption of anaesthetic agents through the gills, so that the substance reaches the CNS faster.

Animals submitted to clove oil had the lowest median times using 60, 70 and $80 \mu \mathrm{L} \mathrm{L}^{-1}$ in relation to the lowest concentration $\left(40 \mu \mathrm{L} \mathrm{L}^{-1} ; \mathrm{p}=0.0000\right)$. The concentrations of 250 and $350 \mu \mathrm{L} \mathrm{L}^{-1}$ of basil oil provoked faster anaesthesia compared to the lower concentration $(p=0.0058)$. Similarly, the concentrations of 500 and $600 \mu \mathrm{L} \mathrm{L}^{-1}$ of tea tree oil induced stage IV more quickly than the two lower concentrations $(p=0.0043)$. The time for anaesthesia induction (stage IV) should not exceed a margin of 180 seconds (Marking and Meyer, 1985; Ross and Ross, 2008). In this study, with the exception of the treatments of 150 and $200 \mu \mathrm{L} \mathrm{L}^{-1}$ of basil oil, it was observed that all other concentrations presented suitable median times for the promotion of anaesthesia, allowing effectiveness in a short-time exposure.

The concentrations of 40 and $50 \mu \mathrm{L} \mathrm{L}^{-1}$ of clove presented faster anaesthesia recovery compared to the concentrations of 60 and $80 \mu \mathrm{L} \mathrm{L}^{-1}$ (Figure 1). The other

Table 1. Anaesthetic stages in fish and characteristic behavior at each stage.

\section{ANAESTHETIC} STAGE

\begin{tabular}{ll}
\hline I - sedation & Loss of reaction to touch and visual perception. \\
II - light anaesthesia & Loss of balance and normal natatory motion interchanged with irregular lateral swimming. \\
III - deep anaesthesia & Total loss of balance, uncoordinated swimming. \\
IV - surgical anaesthesia & Reduction of opercular beatment, absence of natatory motion. \\
V - medullary colapse & Absence of opercular beat, death. \\
\hline
\end{tabular}

Source: Pedrazzani and Ostrensky (2014). 
A

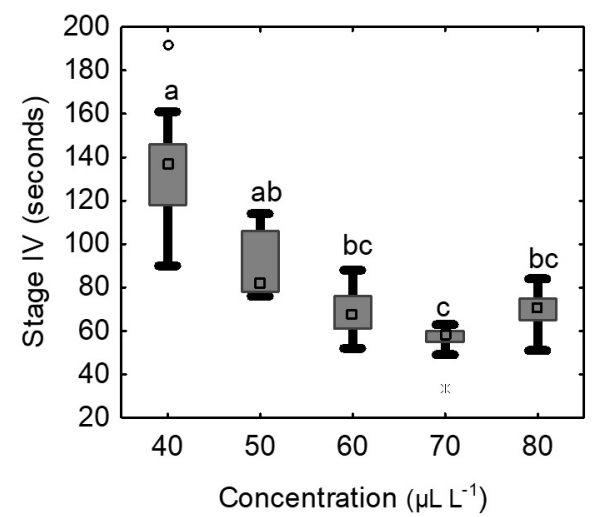

C

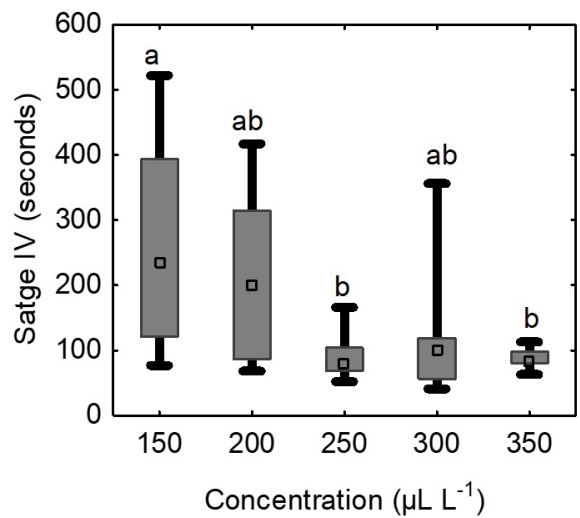

E

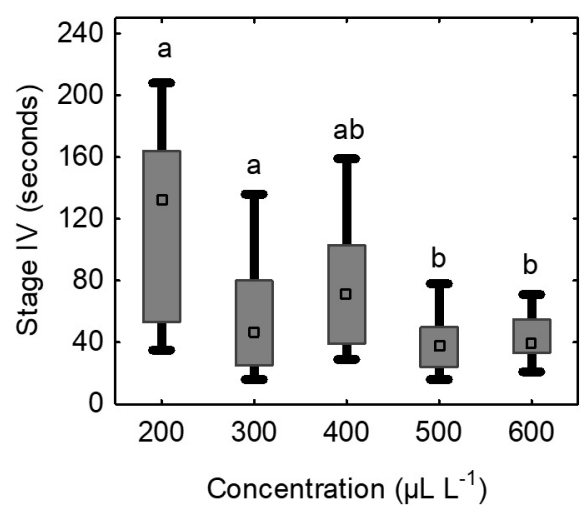

B

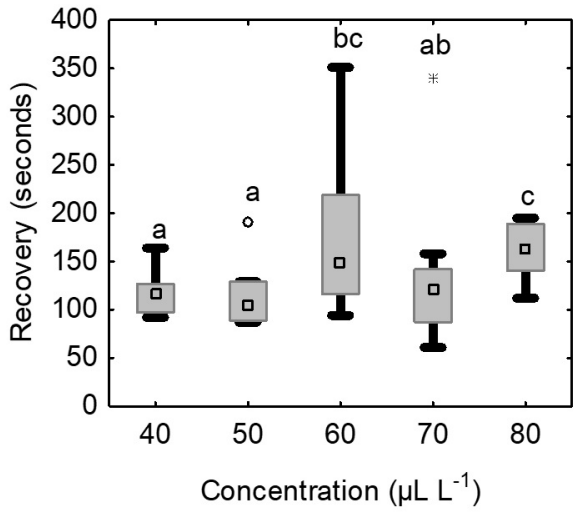

D
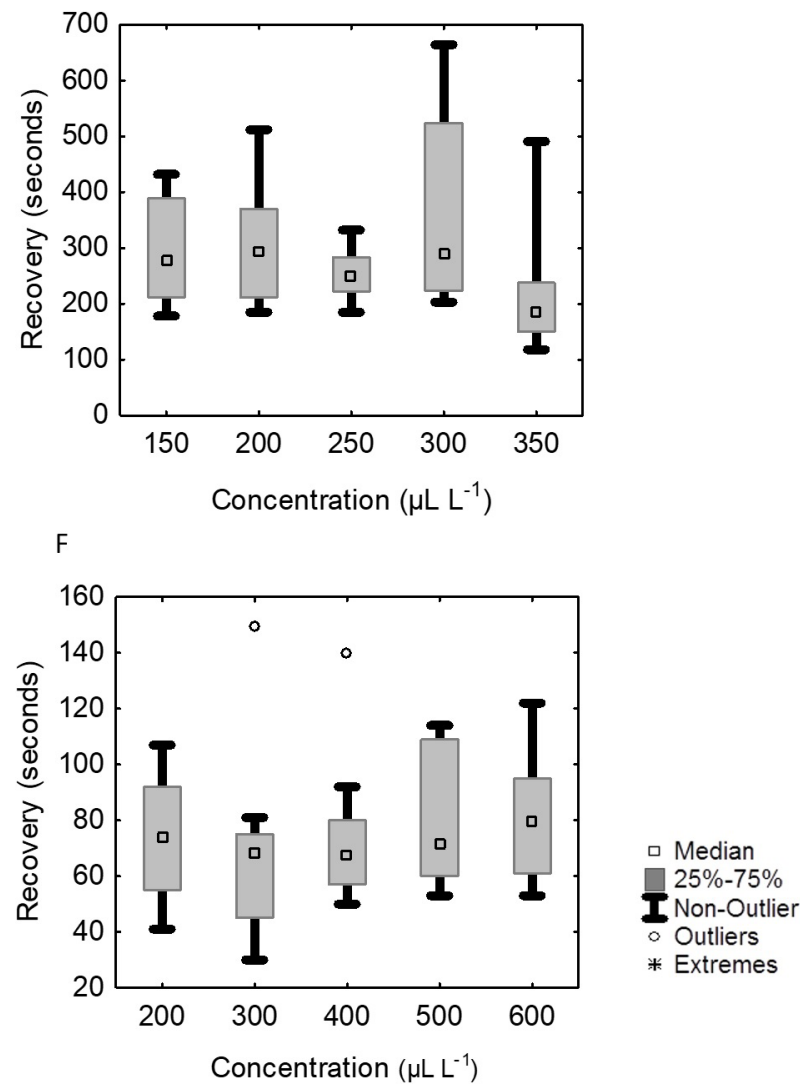

Figure 1. Time (medians) to reach anaesthesia and recovery of Amphiprion clarkii submitted to clove Eugenia caryophyllata (A, B), basil Ocimum basilicum (C, D) and tea tree Melaleuca alternifolia (E, F) essential oils, respectively. Distinct letters indicate statistical significance between treatments $(\mathrm{p}<0.05)$.

EO did not indicate differences for recovery period between their concentrations. All treatments presented median times below the recommended limit of 300 seconds described as the maximum ideal for the return of fish to the basal level, according to Marking and Meyer (1985) and Ross and Ross (2008). When using the basil oil the recovery period was close to the recommended limit (295 seconds), except for the concentration of $300 \mu \mathrm{L} \mathrm{L}^{-1}$, which exceeded this recovery time limit and presented $50 \%$ of the total mortality in this study. This result confirms that the fast elimination of the drugs is safer for animals, because showed that the fish's difficulty in eliminating from its body the basil oil components, possibly toxic for this species, increases the risks to the animal's health.

The linear regression analysis demonstrated there was no correlation between the time of induction and 
anaesthesia recovery in any of the treatments in this study (clove oil: $\mathrm{p}=0.2300, \mathrm{r}=-0.1700$ and $\mathrm{r}^{2}=0.0290$; basil oil: $\mathrm{p}=0.0614, \mathrm{r}=0.2749$ and $\mathrm{r}^{2}=0.0756$; tea tree oil: $\mathrm{p}=0.0521, \mathrm{r}=0.2763$ and $\left.\mathrm{r}^{2}=0.0700\right)$; this was also found by Ostrensky et al. (2015) in lambari Astyanax altiparanae submitted to MS-222 and propofol. The absence of correlation may indicate that the intervals of recovery time are more intensely related with the $A$. clarkii individual capacity to eliminate the drugs from the organism than with the time of exposure to the drug.

Nociception is the neural process of detection of a noxious stimuli that may damage tissue and be potentially painful, usually accompanied by a reflex withdrawal response (Sneddon, 2011). The ability of fish to feel pain is sustained by the presence of nociceptors (delta $\mathrm{A}$ and $\mathrm{C}$ fibres) identical to those of mammals, connected to a comparative brain structure (Sneddon, 2003). It is almost certain that any process that involves invasive methods, such as the use of needles for incisions and sutures, produces some degree of pain (Ross and Ross, 2008).

The present study tested the mechanical noxious stimuli applied to the lips, where there are nociceptors (Sneddon, 2003). In this sense, the analgesia or pain relief in aquatic animals can be considered when they do not respond or decrease the response to painful stimuli after sedation or anaesthesia (Ross and Ross, 2008). It was observed that all of the clove concentrations and the concentration of $250 \mu \mathrm{L} \mathrm{L}^{-1}$ of basil oils provoked an analgesic effect in $100 \%$ of the animals. This effect was also verified in at least $70 \%$ of the fish submitted to the other concentrations of basil and tea tree EO (Table 2). Thus, as indicated by Ross and Ross (2008) that a good anaesthetic should also promote analgesia, this study recommends that, due to its high analgesic efficiency, clove oil should be use when the procedure to be performed with the fish is invasive or likely to generate pain, in order to minimize the effect of noxious stimulus for ethical reasons and to ensure the animal's welfare, avoiding stress and its negative consequences.

All fish anaesthetized with basil had muscle spasms during both anaesthesia induction and handling procedures. In addition, two fish died when transferred to the recovery recipient and another four animals also treated with this EO died during the observation period of 72 hours (Table 2). Silva et al. (2013) also reported constant involuntary muscular contractions followed by mortality in silver catfish Rhamdia quelen submitted to Lippia sidoides, and Benovit et al. (2012) reported the same in flounder anaesthetized with Aloysia gratissima. Basil oil and its main component, methyl chavicol (estragole) are recognized as potential pesticides (Kim and Lee, 2014; Pandey et al., 2014) and, according to Kirby et al. (2000), some insecticides are potent neurotoxins and exert their toxicity by blocking the breakdown of acetylcholine (ACh), the primary neurotransmitter in the sensory and neuromuscular systems of fish. The production of excessive muscular stimulus can be related to the inhibition of acetylcholinesterase (AChE) in the muscles due to this possible increase of ACh levels, which may also result in tetany, paralysis and eventual death (Kirby et al., 2000). Thus, despite the basil present concentrations which promotes analgesic and anaesthetic effects at optimal times of the induction and return, this oil is not indicated for use in $A$. clarkii as it does not meet the basic requirement of safety for animals.

No negative effects occured in the clove and tea tree treatments during anaesthetic exposure or in the 72 hours after it, confirming that these oils are safe for use in fish. Thus, the lower concentrations of each EO that resulted in satisfactory times of anaesthesia induction and recovery and

Table 2. Percentage of Amphiprion clarkii that suffered analgesia and mortality occurred during and after exposure to each concentration of clove Eugenia caryophyllata, basil Ocimum basilicum and tea tree Melaleuca alternifolia essential oils.

\begin{tabular}{|c|c|c|c|c|c|c|c|}
\hline \multirow{2}{*}{ ESSENTIAL OIL } & \multirow{2}{*}{$\begin{array}{c}\text { CONCENTRATION } \\
\left(\mu \mathrm{L} \mathrm{L}^{-1}\right)\end{array}$} & \multirow{2}{*}{$\begin{array}{c}\text { ANALGESIA } \\
(\%)\end{array}$} & \multicolumn{5}{|c|}{ MORTALITY (\%) } \\
\hline & & & $\mathbf{0 H}$ & $24 \mathrm{H}$ & $48 \mathrm{H}$ & $72 \mathrm{H}$ & total \\
\hline \multirow{5}{*}{ Clove } & 40 & 100 & 0 & 0 & 0 & 0 & 0 \\
\hline & 50 & 100 & 0 & 0 & 0 & 0 & 0 \\
\hline & 60 & 100 & 0 & 0 & 0 & 0 & 0 \\
\hline & 70 & 100 & 0 & 0 & 0 & 0 & 0 \\
\hline & 80 & 100 & 0 & 0 & 0 & 0 & 0 \\
\hline \multirow[t]{5}{*}{ Basil } & 150 & 70 & 10 & 0 & 0 & 10 & 20 \\
\hline & 200 & 90 & 0 & 0 & 0 & 0 & 0 \\
\hline & 250 & 100 & 0 & 0 & 0 & 0 & 0 \\
\hline & 300 & 90 & 10 & 10 & 0 & 10 & 30 \\
\hline & 350 & 90 & 0 & 0 & 10 & 0 & 10 \\
\hline \multirow[t]{5}{*}{ Tea tree } & 200 & 90 & 0 & 0 & 0 & 0 & 0 \\
\hline & 300 & 70 & 0 & 0 & 0 & 0 & 0 \\
\hline & 400 & 70 & 0 & 0 & 0 & 0 & 0 \\
\hline & 500 & 90 & 0 & 0 & 0 & 0 & 0 \\
\hline & 600 & 90 & 0 & 0 & 0 & 0 & 0 \\
\hline Control & 0 & 0 & 0 & 0 & 0 & 0 & 0 \\
\hline White & 540 & 0 & 0 & 0 & 0 & 0 & 0 \\
\hline
\end{tabular}


greater analgesia of $A$. clarkii were 50 and $500 \mu \mathrm{L} \mathrm{L}^{-1}$ of clove and tea tree oil, respectively. The $50 \mu \mathrm{L} \mathrm{L}^{-1}$ of clove (equivalent to $52.25 \mathrm{mg} \mathrm{L}^{-1}$ ) recommended in the present study for $A$. clarkii juveniles is similar to the $50 \mathrm{mg} \mathrm{L}^{-1}$ indicated by Pawar et al. (2011) for the anaesthesia of seahorses Hippocampus kuda (total length $15.5 \mathrm{~cm}$ and weight $11 \mathrm{~g}$ ). The concentration of $500 \mu \mathrm{L} \mathrm{L}^{-1}$ of tea tree, recommended here, confers with the dose indicated by Hajek (2011) for anaesthesia of the common carp Cyprinus carpio, weighing $22 \mathrm{~g}$, the only reference found in literature regarding the use of tea tree oil in fish anaesthesia. The use of the same concentrations of each oil to different sizes and species of fish suggests an absence of a relationship between these characteristics with the ideal concentration of the drug, demonstrating that it is important to carry out species-specific studies on the effect of the anaesthetic potential. Therefore the present study contributes to increasing knowledge on the use of these three oils in $A$. clarkii during handling.

\section{Conclusion}

All the EO provoked anaesthesia and analgesic effects in A. clarkii, but basil oil is not recommended due to the resulting involuntary muscle contractions and mortality. The lower concentrations that promote suitable induction and recovery times are 50 and $500 \mu 1 \mathrm{~L}^{-1}$ of clove and tea tree oils, respectively. However, clove oil is recommended as the ideal anaesthetic to use before invasive and painful procedures, due to its better analgesic efficiency in A. clarkii juveniles.

\section{Acknowledgements}

To CAPES (Coordination for the Improvement of Higher Level Personnel) for providing the master's and post-doctoral scholarships.

\section{References}

BENOVIT, S.C., GRESSLER, L.T., SILVA, L.L., GARCIA, L.O., OKAMOTO, M.H., PEDRON, J.S., SAMPAIO, L.A., RODRIGUES, R.V., HEINZMANN, B.M. and BALDISSEROTTO, B., 2012. Anesthesia and Transport of Brazilian Flounder, Paralichthys orbignyanus, with Essential Oils of Aloysia gratissima and Ocimum gratissimum. Journal of the World Aquaculture Society, vol. 43, no. 6, pp. 896-900. http:// dx.doi.org/10.1111/j.1749-7345.2012.00604.x.

BERGQVIST, J. and GUNNARSSON, S., 2013. Finfish aquaculture: Animal welfare, the environment and ethical implications. Journal of Agricultural \& Environmental Ethics, vol. 26, no. 1, pp. 75-99. http://dx.doi.org/10.1007/s10806-011-9346-y.

BILAL, A., JAHAN, N., AHMED, A., BILAL, S.N., HABIB, S. and HAJRA, S., 2012. Phytochemical and pharmacological studies on Ocimum basilicum Linn: a review. International Journal of Current Research and Review, vol. 4, pp. 73-83.

BOIJINK, C.L., MACIEL, P.O., TAVARES-DIAS, M., IWASHITA, M.K.P., MORAIS, M.S., HIDE, D.M.V., SOUZA, N.C., COUTO, M.V.S., MENESES, J.O., CUNHA, F.S. and
FUJIMOTO, R.Y., 2017. Anesthesia by sprinkling method in the gills of tambaqui Colossoma macropomum does not influence intensity and morphology of monogeneans. Brazilian Journal of Biology $=$ Revista Brasileira de Biologia, vol. 77, no. 2, pp. 367-371. http://dx.doi.org/10.1590/1519-6984.15915.

CARSON, C.F., HAMMER, K.A. and RILEY, T.V., 2006. Melaleuca alternifolia (tea tree) oil: a review of antimicrobial and other medicinal properties. Clinical Microbiology Reviews, vol. 19, no. 1, pp. 50-62. PMid:16418522. http://dx.doi.org/10.1128/ CMR.19.1.50-62.2006.

HAJEK, G.J., 2011. The anaesthetic-like effect of tea tree oil in common carp Cyprinus carpio L. Aquaculture Research, vol. 42 , no. 2 , pp. 296-300. http://dx.doi.org/10.1111/j.13652109.2010.02625.x.

INOUE, L.A.K.A., SANTOS-NETO, C.D. and MORAES, G., 2003. Clove oil as anaesthetic for juveniles of matrinxã Brycon cephalus (Gunther, 1869). Ciência Rural, vol. 33, no. 5, pp. 943-947. http://dx.doi.org/10.1590/S0103-84782003000500023.

IVERSEN, M., FINSTAD, B., MCKINLEY, R.S. and ELIASSEN, R.A., 2003. The efficacy of metomidate, clove oil, Aqui-S ${ }^{\mathrm{TM}}$ and Benzoak ${ }^{\circledR}$ as anaesthetics in Atlantic salmon (Salmo salar L.) smolts, and their potential stress-reducing capacity. Aquaculture, vol. 221, no. 1-4, pp. 549-566. http://dx.doi.org/10.1016/S00448486(03)00111-X.

JOHNSTON, G., KAISER, H., HECHT, T. and OELLERMANN, L., 2003. Effect of ration size and feeding frequency on growth, size distribution and survival of juvenile clownfish, Amphiprion percula. Journal of Applied Ichthyology, vol. 19, no. 1, pp. 40-43. http://dx.doi.org/10.1046/j.1439-0426.2003.00351.x.

KIM, S.I. and LEE, D.W., 2014. Toxicity of basil and orange essential oils and their components against two coleopteran stored products insect pests. Journal of Asia-Pacific Entomology, vol. 17, no. 1, pp. 13-17. http://dx.doi.org/10.1016/j.aspen.2013.09.002.

KIRBY, M.F., MORRIS, S., HURST, M., KIRBY, S.J., NEALL, P., TYLOR, T. and FAGG, A., 2000. The use of cholinesterase activity in flounder (Platichthys flesus) muscle tissue as a biomarker of neurotoxic contamination in UK estuaries. Marine Pollution Bulletin, vol. 40, no. 9, pp. 780-791. http://dx.doi.org/10.1016/ S0025-326X(00)00069-2.

MARKING, L.L. and MEYER, F.P., 1985. Are better fish anesthetics needed in fisheries? Fisheries, vol. 10, no. 6, pp. 2-5. http://dx.doi.org/10.1577/1548-8446(1985)010<0002:AB $\mathrm{ANIF}>2.0 . \mathrm{CO} ; 2$

OSTRENSKY, A., PEDRAZZANI, A.S. and VICENTE, A.L., 2015. Use of MS-222 (tricaine methanesulfonate) andpropofol (2,6-diisopropylphenol) as anaesthetics for the tetra Astyanax altiparanae (Teleostei, Characidae). Aquaculture Research, vol. 47, no. 1, pp. 3477-3488. http://dx.doi.org/10.1111/are.12797.

PANDEY, A.K., SINGH, P. and TRIPATHI, N.N., 2014. Chemistry and bioactivities of essential oils of some Ocimum species: an overview. Asian Pacific Journal of Tropical Biomedicine, vol. 4, no. 9, pp. 682-694. http://dx.doi.org/10.12980/APJTB.4.2014C77.

PARK, M.O., HUR, W.J., IM, S.Y., SEOL, D.W., LEE, J. and PARK, I.S., 2008. Anaesthetic efficacy and physiological responses to clove oil-anaesthetized kelp grouper Epinephelus bruneus. Aquaculture Research, vol. 39, no. 8, pp. 877-884. http://dx.doi. org/10.1111/j.1365-2109.2008.01941.X.

PAWAR, H.B., SANAYE, S.V., SREEPADA, R.A., HARISH, V., SURYAVANSHI, U., TANU. and ANSARI, Z.A., 2011. 
Comparative efficacy of four anaesthetic agents in the yellow seahorse, Hippocampus kuda (Bleeker, 1852). Aquaculture, vol. 311, no. 1-4, pp. 155-161. http://dx.doi.org/10.1016/j. aquaculture.2010.12.007

PEDRAZZANI, A.S. and OSTRENSKY, A., 2014. The anaesthetic effect of camphor (Cinnamomum camphora), clove (Syzygium aromaticum) and mint (Mentha arvensis) essential oils on clown anemonefish, Amphiprion ocellaris (Cuvier 1830). Aquaculture Research, vol. 47, no. 3, pp. 769-776. http://dx.doi. org/10.1111/are.12535.

PINSKY, M.L., MONTES JUNIOR, H.R. and PALUMBI, S.R., 2010. Using isolation by distance and effective density to estimate dispersal scales in anemonefish. Evolution, vol. 64, no. 9, pp. 2688-2700. PMid:20394657. http://dx.doi.org/10.1111/j.15585646.2010.01003.x.

PIRHONEN, J. and SCHRECK, C.B., 2003. Effects of anaesthesia with MS-222, clove oil and $\mathrm{CO}_{2}$ on feed intake and plasma cortisol in steelhead trout (Oncorhynchus mykiss). Aquaculture, vol. 220, no. 1-4, pp. 507-514. http://dx.doi.org/10.1016/S00448486(02)00624-5.

ROSS, L.G. and ROSS, B., 2008. Anaesthetic and sedative techniques for aquatic animals. 3rd ed. Oxford: Blackwell Publishing. 236 p. http://dx.doi.org/10.1002/9781444302264.

SEPULCHRO, L.C.O., CARVALHO, M.A. and GOMES, L.C., 2016. Salinity does not alter the effectiveness of menthol as an anesthetic and sedative during the handling and transport of juvenile fat snook (Centropomus parallelus). Brazilian Journal of Biology $=$ Revista Brasileira de Biologia, vol. 76, no. 3, pp. 757763. PMid:27097096. http://dx.doi.org/10.1590/1519-6984.04115.

SILVA, L.D.L., SILVA, D.T., GARLET, Q.I., CUNHA, M.A., MALLMANN, C.A., BALDISSEROTTO, B., LONGHI, S.J., PEREIRA, A.M.S. and HEINZMANN, B.M., 2013. Anesthetic activity of Brazilian native plants in silver cat fish (Rhamdia quelen). Neotropical Ichthyology, vol. 11, no. 2, pp. 443-451. http://dx.doi.org/10.1590/S1679-62252013000200014.

SNEDDON, L.U., 2003. Trigeminal somatosensory innervation of the head of a teleost fish with particular reference to nociception. Brain Research, vol. 972, no. 1-2, pp. 44-52. PMid:12711077. http://dx.doi.org/10.1016/S0006-8993(03)02483-1.

SNEDDON, L.U., 2011. Sensory systems, perception, and learning: nociception or pain in fish. In: A.P. FARRELL, ed. Encyclopedia of fish physiology: from genome to environment. Oxford: Academic Press, pp. 713-719.

SOTO, C.G. and BURHANUDDIN, C.G., 1995. Clove oil as a fish anesthetic for measuring length and weight of rabbit fish (Siganus lineatus). Aquaculture, vol. 136, no. 1-2, pp. 149-152. http://dx.doi.org/10.1016/0044-8486(95)01051-3.

SOUZA, R.A.R., CARVALHO, C.V.A., NUNES, F.F., SCOPEL, B.R., GUARIZI, J.D. and TSUZUKI, M.Y., 2012. Efeito comparativo da benzocaína, mentol e eugenol como anestésicos para juvenis de robalo peva. Boletim do Instituto de Pesca, vol. 38 , no. 3, pp. 247-255.

WEBER III, E.S., 2011. Fish analgesia: pain, stress, fear aversion, or nociception? The Veterinary Clinics of North America. Exotic Animal Practice, vol. 14, no. 1, pp. 21-32. PMid:21074700. http:// dx.doi.org/10.1016/j.cvex.2010.09.002.

WEBER, R.A., PELETEIRO, J.B., GARCÍA-MARTÍN, L.O. and ALDEGUNDE, M., 2009. The efficacy of 2-phenoxyethanol, metomidate, clove oil and MS-222 as anaesthetic agents in the Senegalese sole (Solea senegalensis Kaup 1858). Aquaculture, vol. 288, no. 1-2, pp. 147-150. http://dx.doi.org/10.1016/j. aquaculture.2008.11.024.

YE, L., YANG, S.Y., ZHU, X.M., LIU, M., LIN, J.Y. and WU, K.C., 2011. Effects of temperature on survival, development, growth and feeding of larvae of yellowtail clownfish Amphiprion clarkii (Pisces: Perciformes). Acta Ecologica Sinica, vol. 31, no. 5, pp. 241-245. http://dx.doi.org/10.1016/j.chnaes.2011.06.003. 